\title{
ABM Clinical Protocol \#8: Human Milk Storage Information for Home Use for Full-Term Infants (Original Protocol March 2004; Revision \#1 March 2010)
}

\author{
The Academy of Breastfeeding Medicine Protocol Committee
}

A central goal of The Academy of Breastfeeding Medicine is the development of clinical protocols for managing common medical problems that may impact breastfeeding success. These protocols serve only as guidelines for the care of breastfeeding mothers and infants and do not delineate an exclusive course of treatment or serve as standards of medical care. Variations in treatment may be appropriate according to the needs of an individual patient.

\section{Background}

B REASTFEEDING MOTHERS may encounter unforeseen reasons for separation from their infants, but more often women need to express and store milk for planned events, lifestyle flexibility, and returning to work. Knowledge of appropriate human milk handling and storage is essential for breastfeeding success.

Human milk is a fresh, living food with many antioxidant, antibacterial, prebiotic, probiotic, and immune-boosting properties in addition to nutrients. Although some of these nutrients and health properties change with storage, there is good evidence that human milk storage can be safe, allowing provision of optimal nutrition to the child when nursing or immediately expressed milk is not available. Stored human milk maintains its unique qualities such that it continues to be the gold standard for infant feeding, superior to artificial feeding.

\section{Preparation for Human Milk Storage}

1. Women should wash their hands with soap and water, or a waterless hand cleanser if their hands don't appear dirty, before milk expression. Unclean hands may transmit viruses and bacteria, some of which can cause illness. Studies show that human milk containing fewer bacteria at the time of expression develops less bacterial growth during storage and has higher protein levels compared to milk that has an abundance of bacteria. ${ }^{1-3}$

2. Milk expression can be achieved by hand or by a pump. There are many factors involved in pump selection, such as cost, availability of pumps, access to electricity, anticipated frequency and ongoing duration of expression, time constraints, comfort, etc. As long as the appropriate steps are taken for hand cleansing and cleaning of pump parts as per the pump manufacturer, there does not seem to be a difference in milk contamination with pumping versus manual expression. ${ }^{4,5}$ One study investigated fat concen- tration in expressed milk with manual expression versus pumping and found no difference. ${ }^{6}$

3. Several studies have been done to evaluate storage containers. Glass and polypropylene containers appear similar in their effects on adherence of lipid-soluble nutrients to the container surface, ${ }^{6}$ the concentration of immunoglobulin $\mathrm{A}$, and the numbers of viable white blood cells in the stored milk. ${ }^{7}$ Use of polyethylene containers was associated with a marked drop (60\%) of immunoglobulin A. ${ }^{7}$ Steel containers were associated with a marked decline in cell count and cell viability when compared to polyethylene ${ }^{8}$ and to glass. ${ }^{9}$ There has been concern about possible contamination of milk stored in polypropylene bags because of the risk of contamination by puncturing the plastic. ${ }^{10}$ Therefore, plastic bags used for human milk storage should be sturdy, sealed well, and stored in an area where damage to the bag would be minimized. Concern has also been raised about the risk of breaking glass containers. Containers made with bisphenol A, which is found in several plastic containers including baby bottles, should be avoided based on strong evidence of its adverse effects as an endocrine disruptor. ${ }^{11}$

4. Containers for human milk storage do not need to be sterilized. They can be washed in hot soapy water and rinsed or washed in a dishwasher. ${ }^{4}$ If soap is not available, then boiling water is preferable.

5. There is no need to discard the first few drops of milk when initiating milk expression. This milk is not more likely to be contaminated than milk that is subsequently expressed. ${ }^{4}$

6. Breasts/nipples do not need to be washed prior to expression. ${ }^{4}$

\section{Storage of Human Milk}

1. Freshly expressed human milk may be stored safely at room temperature $\left(10-29^{\circ} \mathrm{C}, 50-85^{\circ} \mathrm{F}\right)$. Different studies 
suggest different optimal times for room temperature storage because the studies vary greatly in the cleanliness of milk expression technique and the room temperature during the study. Warmer ambient temperatures are associated with faster growing bacterial counts in stored milk. For room temperatures ranging from $27^{\circ} \mathrm{C}$ to $32^{\circ} \mathrm{C}\left(29^{\circ} \mathrm{C}=85^{\circ} \mathrm{F}\right), 3-4$ hours may be a reasonable limit. ${ }^{3,12,13}$ For very clean expressed milk with very little bacteria, 6-8 hours at lower room temperatures may be reasonable. ${ }^{2,14-16}$

2. Very few studies have evaluated milk storage safety at $15^{\circ} \mathrm{C}\left(59^{\circ} \mathrm{F}\right)$, which would be equivalent to a blue-ice pack in a small cooler. Hamosh et al. ${ }^{12}$ suggested that human milk is safe at $15^{\circ} \mathrm{C}$ for 24 hours, based on minimal bacterial growth noted in the samples from their study.

3. Several studies have demonstrated the safety of refrigerating human milk $\left(4^{\circ} \mathrm{C}, 40^{\circ} \mathrm{F}\right)$, either by evaluating the bactericidal capacity of stored milk as a marker for milk quality or by measuring bacterial growth in the stored milk samples. Bactericidal capacity of stored refrigerated human milk declines significantly by $48-72$ hours. ${ }^{17-19}$ However, studies of expressed human milk with little contamination at the time of expression demonstrate safe, low levels of bacteria growth in milk at 72 hours $^{15}$ and even after 4-8 days of refrigeration. ${ }^{1,2,20}$

4. Freezing expressed human milk $\left(\sim-20^{\circ} \mathrm{C}, 0^{\circ} \mathrm{F}\right)$ has been demonstrated to be safe for at least 3 months. Vitamins A, E, and B, total protein, fat, enzymes, lactose, zinc, immunoglobulins, lysozyme, and lactoferrin are generally preserved when freezing human milk. ${ }^{21-23} \mathrm{~A}$ few studies have found a significant decrease in vitamin $C$ levels in frozen milk after 3 months. ${ }^{24,25}$ Bacterial growth was not found to be a problem in frozen milk for at least 6 weeks. ${ }^{26}$ Antibacterial activity of frozen human milk is preserved for at least 3 weeks. ${ }^{27}$ The basic principles of freezing dictate that frozen foods at $-18^{\circ} \mathrm{C}\left(0^{\circ} \mathrm{F}\right)$ are indefinitely safe from bacterial contamination, although enzymatic processes inherent in food could persist, with possible changes in milk quality. ${ }^{28}$ Frozen human milk should be stored in the back of the freezer to prevent intermittent rewarming due to freezer door opening. All containers with human milk should be well sealed to prevent contamination.

5. After a container is filled with human milk, space should be left at the top of the container to allow for expansion with freezing. All stored containers of human milk should be labeled with the date of milk expression and the name of the child if the milk will be used in a child-care setting. It is typical for infants in daycare to take $60-120 \mathrm{~mL}$ (2-4 ounces) of human milk at one feeding. Therefore, storing human milk in 60$120-\mathrm{mL}$ increments is a convenient way to prevent waste of defrosted/thawed human milk.

6. Try to avoid adding warm milk to already cooled or frozen milk, in order to prevent rewarming of the already stored milk. It is best to cool down the newly expressed milk first before adding it to older stored milk.

7. Stored human milk may have an altered smell and taste because of the activity of lipase, an enzyme that breaks down fat into fatty acids. This breakdown of fat aids the infant in the digestion of human milk, particularly for preterm infants, and is not harmful, ${ }^{28,29}$ although some infants may refuse to drink it. Heating milk to above $40^{\circ} \mathrm{C}$ is not advised because this will result in loss of enzyme activity. ${ }^{29}$

A summary of milk storage guidelines is given in Table 1 .

\section{Using Stored Human Milk}

1. Fresh milk is better than frozen milk. Use the oldest milk in the refrigerator or freezer first.

2. The baby may drink the milk cool, at room temperature, or warmed. Infants may demonstrate a preference.

3. It is best to defrost human milk either in the refrigerator overnight, by running under warm water, or setting it in a container of warm water. Studies done on defrosting human milk in a microwave demonstrate that controlling the temperature in a microwave is difficult, causing the milk to heat unevenly. ${ }^{30}$ Although microwaving milk decreases bacteria in the milk much like pasteurization does, microwaving also significantly decreases the anti-infective quality of human milk, which may reduce its overall health properties for the infant. $^{31,32}$

4. Once frozen milk is brought to room temperature, its ability to inhibit bacterial growth is lessened, especially by 24 hours after thawing. ${ }^{27}$ Previously frozen human milk that has been thawed for 24 hours should not be left out at room temperature for more than a few hours.

5. There is little information on refreezing of thawed human milk. Bacterial growth and loss of antibacterial activity in thawed milk will vary depending on the

Table 1. Milk Storage Guidelines

\begin{tabular}{lcc}
\hline Location of storage & Temperature & $\begin{array}{c}\text { Maximum recommended } \\
\text { storage duration }\end{array}$ \\
\hline Room temperature & $16-29^{\circ} \mathrm{C}\left(60-85^{\circ} \mathrm{F}\right)$ & $3-4$ hours optimal \\
& $6-8$ hours acceptable under \\
very clean conditions & 72 hours optimal \\
Refrigerator & $\leq 4^{\circ} \mathrm{C}\left(39^{\circ} \mathrm{F}\right)$ & $5-8$ days under very \\
& & clean conditions \\
Freezer & $<-17^{\circ} \mathrm{C}\left(0^{\circ} \mathrm{F}\right)$ & 12 months optimal acceptable \\
\hline
\end{tabular}


technique of milk thawing, duration of the thaw, and the amount of bacteria in the milk at the time of expression. At this time no recommendations can be made on the refreezing of thawed human milk.

6. Once a baby begins drinking expressed human milk, some bacterial contamination occurs in the milk from the baby's mouth. The duration of time the milk can be kept at room temperature once the baby has partially fed from the cup or bottle would theoretically depend on the initial bacterial load in the milk, how long the milk has been thawed, and the ambient temperature. There have been no studies done to provide recommendations in this regard. Based on related evidence thus far, it seems reasonable to discard the remaining milk within 1-2 hours after the baby is finished feeding.

7. Expressed human milk does not require special handling (such as universal precautions), as is required for other bodily fluids such as blood. It can be stored in a workplace refrigerator where other workers store food, although it should be labeled with name and date. ${ }^{33}$ Mothers may prefer to store their milk in a personal freezer pack.

8. Uncontaminated human milk naturally contains nonpathogenic bacteria $^{34,35}$ and is important in establishing the neonatal intestinal flora. These bacteria are probioticsthey create conditions in the intestine that are unfavorable to the growth of pathogenic organisms. ${ }^{35}$ If a mother has breast or nipple pain from what is considered to be a bacterial or yeast infection, there is no evidence that her stored expressed milk needs to be discarded. Human milk that appears stringy, foul, or purulent should not be fed to the baby.

\section{Areas for Future Research}

The evidence for human milk storage is based on older, small, nonreproduced studies that are difficult to compare. The studies vary greatly in most respects, such as technique of milk collection, cleanliness and types of containers, duration of storage, method of thawing milk, temperature and type of storage unit, and culture techniques of milk samples. Several studies tried to mimic typical behaviors of human milk expression, storage, thawing, and use in their communities. Large high-quality studies in evaluating human milk storage in a variety of circumstances over a longer duration of time are greatly needed. Standards for evaluating milk quality, such as culture techniques, need to be established. Although it is ideal to have a universal international guideline for human milk storage, it may be impossible for one guideline to represent unusual or limited circumstances in some cultures.

These studies vary greatly in how the lactating subjects collected their milk. Human milk naturally has commensal organisms that have been shown to be prebiotic and to be essential in establishing the microbacterial environment in the neonatal intestine. The infant intestine may be affected by other flourishing bacteria introduced via contamination in the process of human milk collection. Feeding an infant stored human milk may have different consequences on infant intestinal health as compared to breastfeeding, and this should be investigated further. Along these same lines, stored human milk changes in quality over time, as demonstrated by many of the referenced articles included in this protocol. The effect of stored human milk versus fresh human milk on the health of a child should be studied.

There is also no agreed-upon definition of unsafe milk. Several studies describe the degree of milk contamination over a period of time under certain temperature and storage time conditions, typically described as the number of colonyforming units per milliliter. There is no accepted limit at which point milk should not be consumed, although $1 \times 10^{4}$ colonyforming units $/ \mathrm{mL}$ has been suggested. Other studies have investigated the bactericidal capacity of stored human milk, which would reflect its immunologic effectiveness for the baby and the risk of the milk becoming contaminated over time during storage. The percentage loss of bactericidal activity that would render human milk unfit has not been defined. A definition for adequate milk quality should be established, with guidelines on what would constitute unsafe milk or lower-quality milk necessitating supplementation.

There are no studies that have investigated human milk quality after 6-12 months of freezing. Because this is a widely accepted method of preserving human milk and because some babies' nutrition rely entirely on frozen human milk, studies should be done to confirm that this is nutritionally safe.

\section{Acknowledgments}

This work was supported in part by a grant from the Maternal and Child Health Bureau, U.S. Department of Health and Human Services.

\section{References}

1. Sosa R, Barness L. Bacterial growth in refrigerated human milk. Am J Dis Child 1987;141:111-112.

2. Pardou A, Serruys E, Mascart-Lemone F, et al. Human milk banking: Influence of storage processes and of bacterial contamination on some milk constituents. Biol Neonate 1994;65:302-309.

3. Eteng MU, Ebong PE, Eyong EU, et al. Storage beyond three hours at ambient temperature alters the biochemical and nutritional qualities of breastmilk. Afr J Reprod Health 2001;5:130-134.

4. Pittard WB $3^{\text {rd }}$, Geddes KM, Brown S, et al. Bacterial contamination of human milk: Container type and method of expression. Am J Perinatol 1991;81:25-27.

5. Boo NY, Nordiah AJ, Alfizah H, et al. Contamination of breast milk obtained by manual expression and breast pumps in mothers of very low birthweight infants. J Hosp Infect 2001;49:274-281.

6. Garza C, Johnson CA, Harrist R, et al. Effects of methods of collection and storage on nutrients in human milk. Early Hum Dev 1982;6:295-303.

7. Goldblum RM, Garza C, Johnson CA, et al. Human milk banking I. Effects of container upon immunologic factors in human milk. Nutr Res 1981;1:449-459.

8. Manohar AA, Williamson M, Koppikar GV. Effect of storage of colostrum in various containers. Indian Pediatr 1997;34: 293-295.

9. Williamson MT, Murti PK. Effect of storage, time, temperature, and composition of containers on biologic components of human milk J Hum Lact 1996;12:31-35.

10. Hopkinson J, Garza C, Asquith MT. Human milk storage in glass containers J Hum Lact 1990;6:104-105. 
11. Vom Saal FS, Hughes C. An extensive new literature concerning low dose effects of bisphenol A shows the need for a new risk assessment. Environ Health Perspect 2005;113: 926-933.

12. Hamosh M, Ellis LA, Pollock DR, et al. Breastfeeding and the working mother: Effect of time and temperature of shortterm storage on proteolysis, lipolysis, and bacterial growth in milk. Pediatrics 1996;97:492-498.

13. Nwankwo MU, Offor E, Okkolo AA, et al Bacterial growth in expressed breast milk. Ann Trop Paediatr 1988;8:92-95.

14. Pittard WB $3^{\text {rd }}$, Anderson DM, Cerutti ER, et al. Bacteriostatic qualities of human milk. J Pediatr 1985;107;240-243.

15. Igumbor EO, Mukura RD, Makandiramba B, et al. Storage of breast milk: Effect of temperature and storage duration on microbial growth. Centr Afr J Med 2000;46:247-251.

16. Ajusi JD, Onyango FE, Mutanda LN, et al. Bacteriology of unheated expressed breastmilk stored at room temperature. East Afr Med J 1989;66:381-387.

17. Martínez-Costa C, Silvestre MD, López MC, et al. Effects of refrigeration on the bactericidal activity of human milk: A preliminary study. J Pediatr Gastroenterol Nutr 2007;45:275-277.

18. Silvestre D, Lopez MC, March L, et al. Bactericidal activity of human milk: Stability during storage. $\mathrm{Br} J$ Biomed Sci 2006;63:59-62.

19. Ogundele MO. Effects of storage on the physicochemical and antibacterial properties of human milk. Br J Biomed Sci 2002;59:205-211.

20. Slutzah M, Codipilly CN, Potak D, et al. Refrigerator storage of expressed human milk in the neonatal intensive care unit. J Pediatr 2010;156:26-28.

21. Ezz El Din ZM, Abd El Ghaffar S, El Gabry EK, et al. Is stored expressed breast milk an alternative for working Egyptian mothers? East Mediterr Health J 2004;10:815-821.

22. Friend BA, Shahani KM, Long CA, et al. The effect of processing and storage on key enzymes, $\mathrm{B}$ vitamins, and lipids of mature human milk. I. Evaluation of fresh samples and effects of freezing and frozen storage. Pediatr Res 1983;17: 61-64.

23. Evans TJ, Ryley HC, Neale LM, et al. Effect of storage and heat on antimicrobial proteins in human milk. Arch Dis Child 1978;53:239-241.

24. Buss IH, McGill F, Barlow BA, et al. Vitamin C is reduced in human milk after storage. Acta Paediatr 2001;90:813-815.

25. Bank MR, Kirksey A, West K, et al. Effect of storage time and temperature on folacin and vitamin $C$ levels in term and preterm human milk. Am J Clin Nutr 1985;41:235-242.

26. Marín ML, Arroyo R, Jiménez E, et al. Cold storage of human milk: Effect on its bacterial composition. J Pediatr Gastroenterol Nutr 2009;49:343-348.

27. Hernandez J, Lemons P, Lemons J, et al. Effect of storage processes on the bacterial growth-inhibiting activity of human breast milk. Pediatrics 1979;63:597-601.
28. Food Safety and Inspection Service, U.S. Department of Agriculture. October 2005. http://www.fsis.usda.gov/Fact_ Sheets/Focus_On_Freezing/index.asp (last accessed March 10, 2010).

29. Wardell JM, Wright AJ, Bardsley WG, et al. Bile salt stimulated lipase and esterase activity in human milk after collection, storage, and heating: Nutritional implications. Pediatr Res 1984;18:382-386.

30. Ovesen L, Jakobsen J, Leth $\mathrm{T}$, et al. The effect of microwave heating on vitamins B1 and E, and linoleic and linolenic acids, and immunoglobulins in human milk. Int J Food Sci Nutr 1996;47:427-436.

31. Quan R, Yang C, Rubinstein S, et al. Effects of microwave radiation on anti-infective factors in human milk. Pediatrics 1992;89:667-669.

32. Sigman M, Burke KI, Swarner OW, et al. Effects of microwaving human milk: Changes in IgA content and bacterial count. J Am Diet Assoc 1989;89:690-692.

33. Centers for Disease Control and Prevention, Department of Health and Human Services. Recommendations on Universal Precautions for Prevention of Transmission of HIV and Other Bloodborne Infections. http://www.cdc.gov/ncidod/ dhqp/bp_universal_precautions.html (last accessed August 26, 2009)

34. Delgado S, Arroyo R, Jimenez E, et al. Mastitis infecciosas durante la lactancia: un problema infravalorado. Acta Pediatr Esp 2009;67:564-571.

35. Heikkilä MP, Saris PEJ. Inhibition of Staphylococcus aureus by the commensal bacteria of human milk. J Appl Microbiol 2003;95:471-478.

ABM protocols expire 5 years from the date of publication. Evidence-based revisions are made within 5 years or sooner if there are significant changes in the evidence.

Contributor

*Anne Eglash, M.D.

Protocol Committee

Maya Bunik, M.D., MSPH, FABM

Caroline J. Chantry, M.D., FABM, Co-Chairperson

Cynthia R. Howard, M.D., MPH, FABM, Co-Chairperson

Ruth A. Lawrence, M.D., FABM

Kathleen A. Marinelli, M.D., FABM, Co-Chairperson

Lawrence Noble, M.D., FABM, Translations Chairperson

Nancy G. Powers, M.D., FABM

Julie Scott Taylor, M.D., M.Sc., FABM

*Lead author

For correspondence: abm@bfmd.org 